\title{
Cantharidin Impairs Cell Migration and Invasion of Human Lung Cancer NCI-H460 Cells via UPA and MAPK Signaling Pathways
}

\author{
TE-CHUN HSIA ${ }^{1,2}$, CHIEN-CHIH YU ${ }^{3}$, YUNG-TING HSIAO ${ }^{4}$, SHIN-HWAR WU ${ }^{5}$, DA-TIAN BAU 6 , \\ HSU-FENG LU ${ }^{7}$, YI-PING HUANG ${ }^{8}$, JAUNG-GENG LIN ${ }^{1}$, SHU-JEN CHANG ${ }^{3 *}$ and JING-GUNG CHUNG ${ }^{4,9 *}$ \\ ${ }^{1}$ Department of Respiratory Therapy, School of Health, China Medical University, Taichung, Taiwan, R.O.C.; \\ ${ }^{2}$ Department of Internal Medicine, China Medical University Hospital, Taichung, Taiwan, R.O.C.; \\ ${ }^{3}$ School of Pharmacy, China Medical University, Taichung, Taiwan, R.O.C.; \\ Departments of ${ }^{4}$ Biological Science and Technology and ${ }^{8}$ Physiology, \\ China Medical University, Taichung, Taiwan, R.O.C.; \\ ${ }^{5}$ Division of Critical Care Medicine, Department of Medicine, \\ Changhua Christian Hospital, Changhua, Taiwan, R.O.C.; \\ ${ }^{6}$ Graduate Institute of Clinical Medical Science, China Medical University, Taichung, Taiwan, R.O.C.; \\ ${ }^{7}$ Department of Clinical Pathology, Cheng Hsin General Hospital, Taipei, Taiwan, R.O.C.; \\ ${ }^{9}$ Department of Biotechnology, Asia University, Wufeng, Taichung, Taiwan, R.O.C.
}

\begin{abstract}
Cantharidin (CTD), a component of natural mylabris (Mylabris phalerata Pallas), has been shown to have biological activities and induce cell death in many human cancer cells. In the present study, we investigated the effect of CTD on cell migration and invasion of NCI-H460 human lung cancer cells. Cell viability was examined and results indicated that CTD decreased the percentage of viable cells in dosedependent manners. CTD inhibited cell migration and invasion in dose-dependent manners. Gelatin zymography analysis was used to measure the activities of matrix metalloproteinases (MMP-2/-9) and the results indicated that CTD inhibited the enzymatic activities of MMP-2/-9 of NCI-H460 cells. Western blotting was used to examine the protein expression of NCIH460 cells after incubation with CTD and the results showed
\end{abstract}

This article is freely accessible online.

*These Authors contributed equally to this study.

Correspondence to: Jing-Gung Chung, $\mathrm{PhD}$, Department of Biological Science and Technology, China Medical University, No 91, Hsueh-Shih Road, Taichung 404, Taiwan, R.O.C. Tel. +886 422053366 (Ext. 8000), Fax: +886 422053764, e-mail: jgchung@mail.cmu.edu.tw and Shu-Jen Chang, Ph.D., School of Pharmacy, China Medical University, No 91, Hsueh-Shih Road, Taichung 404, Taiwan, R.O.C. Tel: +886 422053366 (Ext. 5102), Fax: +886 422031075, e-mail: sjchang@mail.cmu.edu.tw

Key Words: Cantharidin, UPA, migration, invasion, NCI-H460 cells. that CTD decreased the expression of $M M P-2 /-9$, focal adhesion kinase (FAK), Ras homolog gene family, member A (Rho A), phospho-protein kinase $B$ (AKT) (Thr308)(pAKT(308)), phospho-extracellular signal-regulated kinase $1 / 2$ (p-ERK1/2), phospho-p38 mitogen-activated protein (MAP) kinase (p-p38), phospho c-Jun N-terminal kinase $1 / 2$ (p$J N K 1 / 2)$, nuclear factor- $k B \quad(N F-k B)$ and urokinase plasminogen activator (UPA). Furthermore, confocal laser microscopy was used to confirm that CTD suppressed the expression of $N F-k B$ p65, but did not significantly affect protein kinase C (PKC) translocation in NCI-H460 cells. Based on those observations, we suggest that CTD may be used as a novel anticancer metastasis agent for lung cancer in the future.

Lung cancer is the most common cancer among women and men in Taiwan and it is the major cause of death in cancerrelated diseases in the developed world. Neoplastic metastasis is a major cause of cancer-mediated death in humans $(1,2)$. For tumor metastasis, epithelial cancer cells have to migrate from the original primary tumor mass via breaking their cellcell contacts (adherens junctions) to form cancer mass in a new site $(3,4)$; thus, tumor metastasis involves cell attachment (adhension), migration and invasion in order to form a new tumor in another site of the body. Inhibiting cancer cell metastasis is one of the important steps for cancer therapy and research (5). Numerous evidence have shown that multiple factors involved in tumor metastasis, such as the activation of PI3K/Akt pathway (6), matrix metalloproteinases (MMPs)-enzymes that can degrade the extracellular matrix and 
basement membrane collagen for cells to invade $(7,8)$ - and urokinase plasminogen activator (UPA), also play an important role for degrading extracellular matrix (9).

In most types of human cancers, MMPs have been found to be up-regulated, while overexpression of MMPs is correlated with invasive and metastatic properties of cancer $(10,11)$. MMP-2 and -9 have gelatinase activity and can degrade matrix collagen and basement membrane $(7,8)$. It has been reported that estrogen can increase expression of vascular endothelial growth factor (VEGF) and activate the extracellular signal-regulated kinase1/2 (ERK1/2) pathway to induce MMP-2/-9 expression (12). Thus, MMP-2/-9 have been the focus on targeting of anticancer drug development due to their role that is associated with cancer cells' attachment, migration and invasion or metastasis (13). UPA has been shown to be involved in cancer cell migration (14) as cell migration is regulated by multiple factors, including signaling cascades, plasmin formation, which is generated by the proteolytic cleavage of plasminogen by UPA, plasminmediated proteolysis of the extracellular matrix and cell adhesion (15). Thus, the inhibition of migration and invasion of cancer cells, which is mediated by MMP-2/-9 or UPA, could be a preventive mechanism for cancer metastasis (13).

Cantharidin (CTD), a terpenoid, is isolated from blister beetles, with the dried bodies of these beetles being used to treat many types of cancer in Chinese population (16). CTD, the active ingredient of blister beetle, has been reported to be an inhibitor of protein phosphatases 1 and $2 \mathrm{a}$ (17) that have biological activity, such as cytotoxic effects to induce DNA damage in cancer cells (18) and $\mathrm{G}_{2} / \mathrm{M}$ phase arrest of cell-cycle distribution and induction of apoptosis $(19,20)$. Furthermore, CTD has also been reported to induce apoptosis in human cancer, such as bladder $(21,22)$, breast (23), liver cancer (24) and multiple myeloma (25). A diluted solution of CTD has been used experimentally as a topical medication to remove warts (26).

Although a great amount of evidence has shown that CTD induces cytotoxic cell death of cancer cells through cell cycle arrest and induction of apoptosis, there is no available information showing that CTD can inhibit migration and invasion of human lung cancer NCI-H460 cells. Therefore, the aim of the present study was to better clarify the molecular mechanisms of CTD in the suppression of migration and invasion of human lung cancer NCI-H460 cells in vitro. This is the first report showing that the anti-metastatic activity of CTD proceeds via phosphatidylinositol-4 5-bisphosphate 3kinase (PI3K) and MMP-2/-9 inhibition.

\section{Materials and Methods}

Chemicals and reagents. Cantharidin (CTD), dimethyl sulfoxide (DMSO) and propidium iodide (PI) were obtained from Sigma Chemical Co. (St. Louis, MO, USA). RPMI-1640, fetal bovine serum (FBS), L-glutamine and penicillin-streptomycin were purchased from GIBCO ${ }^{\circledR} /$ Invitrogen Life Technologies (Carlsbad, CA, USA). Primary antibodies against focal adhesion kinase (FAK), growth factor receptor-bound protein 2 (GRB2), Ras, tissue inhibitor of metalloproteinase (TIMP)2, TIMP1, Ras homolog gene family, member A (Rho A), Rho-associated, coiled-coil-containing protein kinase 1 (ROCK1), PI3K, inositol-requiring enzyme (IRE)$1 \alpha$, mitogen-activated protein (MAP)3K3 (MEKK3), mitogenactivated protein kinase kinase 7 (MKK7), phospho-protein kinase B (AKT) (Thr308) (p-AKT(308)), phospho c-Jun N-terminal kinase 1/2 (p-JNK1/2), phospho-extracellular signal-regulated kinase1/2 (pERK1/2), phospho-p38 mitogen-activated protein (MAP) kinase (pp38), inducible nitric oxide synthase (iNOS), cyclooxygenase (COX)-2, nuclear factor- $\mathrm{kB}$ (NF-kB) p65, MMP-1, -2,- 9, -13, UPA and secondary antibodies were obtained from Cell Signaling Technology, Inc. (Beverly, MA, USA). The enhanced chemiluminescence (ECL) detection system was obtained from Amersham Life Sciences, Inc. (Arlington Heights, IL, USA).

Cell culture. NCI-H460 cells were purchased from the Food Industry Research and Development Institute (Hsinchu, Taiwan). Cells were cultured in RPMI-1640 containing 10\% heat inactivated fetal bovine serum (FBS), $2 \mathrm{mM}$ L-glutamine and antibiotics (100 units $/ \mathrm{ml}$ penicillin, $100 \mu \mathrm{g} / \mathrm{ml}$ streptomycin) in $75 \mathrm{~cm}^{2}$ tissue culture flasks in a humidified atmosphere of $5 \% \mathrm{CO}_{2}$ at $37^{\circ} \mathrm{C}(27)$.

Cells viability assays. NCI-H460 cells were seeded in a 12-well plate at a density of $2 \times 10^{5}$ cells/well and incubated overnight and, then, with or without CTD at $0,1,2.5,5,7.5$ and $10 \mu \mathrm{M}$ or $0.5 \%$ DMSO as a vehicle control for 24 and $48 \mathrm{~h}$. Cells were harvested from each treatment, counted and stained with PI $(5 \mu \mathrm{g} / \mathrm{ml})$. Subsequently, the percentage of viable cells was analyzed by using a flow cytometer (FACS Calibur; BD Biosciences, San Jose, CA, USA) as previously described (28).

Cell migration and invasion assays. Matrigel Cell Migration Assay and Invasion System were used for examining cell migration and invasion as described previously (29-31). Briefly, the cell migration assay that was used with transwell (BD Biosciences, Franklin Lakes, NJ, USA) cell culture chambers ( $8 \mathrm{~mm}$ pore size; Millipore, Billerica, MA, USA) and coated with collagen. NCI-H460 cells $\left(5 \times 10^{4}\right.$ cells/well $)$ were placed in serum-free RPMI-1640 medium for $24 \mathrm{~h}$ and then trypsinized and re-suspended in serum-free medium. The cell suspension was placed in the upper chamber of the transwell insert and incubated with $0.5 \%$ DMSO or CTD $(2.5$ and $5.0 \mu \mathrm{M})$. In the lower chamber, which was containing the $90 \%$ RPMI-1640 medium at $10 \%$ FBS, all cells were incubated for 24 or $48 \mathrm{~h}$. In the lower surface of the filter, the migrating cells were fixed with $4 \%$ formaldehyde in PBS and then stained with $2 \%$ crystal violet in $2 \%$ ethanol, counted and photographed under a light microscope at $\times 200$. The cell invasion assay was performed as the cell migration assay except that the filter membrane was coated with Matrigel from a BioCoat Matrigel invasion kit. Cells migrating to the bottom of the filter, located on the underside of the filter, were examined and counted by using light microscopy at $\times 200$ as described previously $(29,30)$.

Gelatin zymography assay. Gelatin zymography was performed to measure the activities of MMP-2/-9 as described previously (29-31). Briefly, NCI-H460 cells $\left(1 \times 10^{6}\right.$ cells/well $)$ were plated in 6 -well tissue culture plates and then incubated with $0,2.5$ and $5 \mu \mathrm{M}$ of 
CTD in serum-free RPMI- 1640 medium for 24 and $48 \mathrm{~h}$. At the end of incubation, the conditioned medium from each treatment was harvested and the total proteins measured; a $50 \mu \mathrm{g}$ of protein sample was separated by electrophoresis on $10 \%$ SDS-PAGE containing $0.2 \%$ gelatin. The gel was washed twice and soaked in $2.5 \%$ Triton $\mathrm{X}-100$ in $\mathrm{dH}_{2} \mathrm{O}$ twice at $25^{\circ} \mathrm{C}$ for a total of $60 \mathrm{~min}$. Next, the gel was incubated in substrate buffer $\left(50 \mathrm{mM}\right.$ Tris $\mathrm{HCl}, 5 \mathrm{mM} \mathrm{CaCl}_{2}$, $0.02 \% \mathrm{NaN}_{3}$ and $1 \%$ triton $\mathrm{X}-100, \mathrm{pH} 8.0$ ) for $18 \mathrm{~h}$ at $37^{\circ} \mathrm{C}$ while shaking and, finally, stained with $0.2 \%$ Coomassie blue in $10 \%$ acetic acid and 50\% methanol $(29,30)$. MMP-2/-9 gelatinolytic activities were identified by the presence of clear bands with a blue (negative staining) background after de-staining.

Western blotting assay. NCI-H460 cells $\left(1 \times 10^{6}\right)$ were incubated in a $10-\mathrm{cm}$ dish with $0,2.5$ and $5 \mu \mathrm{M}$ of CTD for 24 and $48 \mathrm{~h}$. Cells were harvested and washed once with PBS and the cell pellets were further treated for $30 \mathrm{~min}$ in a lysis buffer ( $40 \mathrm{mM}$ Tris- $\mathrm{HCl}(\mathrm{pH} 7.4), 10 \mathrm{mM}$ EDTA, $120 \mathrm{mM} \mathrm{NaCl}, 1 \mathrm{mM}$ dithiothreitol, $0.1 \%$ Nonidet P-40), with the total protein being determined as described previously $(29,30)$. Each sample containing $30 \mu \mathrm{g}$ of total protein was loaded on a gel $(0 \%$ sodium dodecyl sulphate (SDS)/ polyacrylamide) for Western blot analysis. After electrophoresis, the gel was transferred to a nitrocellulose membrane (Amersham Pharmacia Biotech, Piscataway, NJ, USA) by electro-blotting. Blots were probed by using primary antibodies against FAK, GRB2, Ras, TIMP2, TIMP1, Rho A, ROCK1, PI3K, IRE-1 $\alpha$, MEKK3, MKK7, p-AKT(308), p-JNK1/2, p-ERK1/2, p-p38, iNOS, COX-2, NF-kB p65, MMP-1, -2,- 9, -13, UPA and $\beta$ actin. Then, they were stained with secondary antibody for enhanced chemiluminescence (NEW Life Science Products, Inc, Boston, MA, USA) as described previously. Anti- $\beta$-actin (a mouse monoclonal antibody) was used as a loading control (29-31).

Confocal laser scanning microscopy. NCI-H460 cells $\left(3 \times 10^{5}\right.$ cells/well) were plated on 6-well chamber slides with poly-D-lysine coated glass and grown overnight in RPMI-1640 medium. Cells were treated with $0,2.5$ and $5.0 \mu \mathrm{M}$ of CTD for $24 \mathrm{~h}$, fixed in $3 \%$ formaldehyde in PBS for $15 \mathrm{~min}$ and labeled for immunofluorescence as described previously $(32,33)$. Antibodies against NF-kB p65, PKC, RhoA and ROCK1 were mixed and diluted 1:100, respectively, with blocking buffer. They were then stained with secondary fluorescein isothiocyanate (FITC)conjugated goat anti-mouse IgG at 1:200 dilutions (green fluorescence). Nuclei of each sample were counterstained with PI (Molecular Probes/Invitrogen Corp.) (red fluorescence). Finally, stained cells were examined and photomicrographed using a Confocal Microscope Detection System, Leica TCS SP2 (Leica Microsystems, Heidelberg, Mannheim, Germany) as described previously $(32,33)$.

Statistical analysis. Statistically significant differences between CTD treated and untreated (control) groups were tested by Student's $t$-test. All data are expressed as the means \pm S.D. from at least three experiments. A $p<0.05$ was considered significant.

\section{Results}

CTD decreased the cell viability of NCI-H460 cells. NCIH460 cells were treated with CTD $(0,1,2.5,5.0,7.5$ and $10.0 \mu \mathrm{M}$ ) for 24 and $48 \mathrm{~h}$ before the cells were harvested for viability determination. The results shown in Figure 1A and
(A)

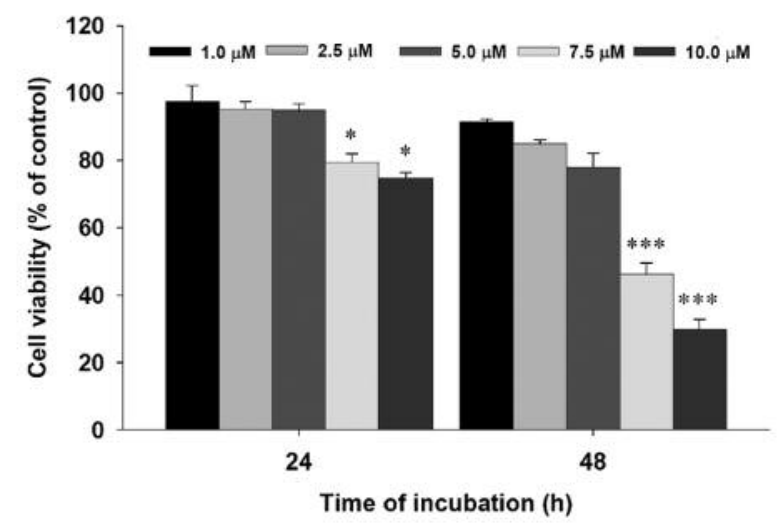

(B)

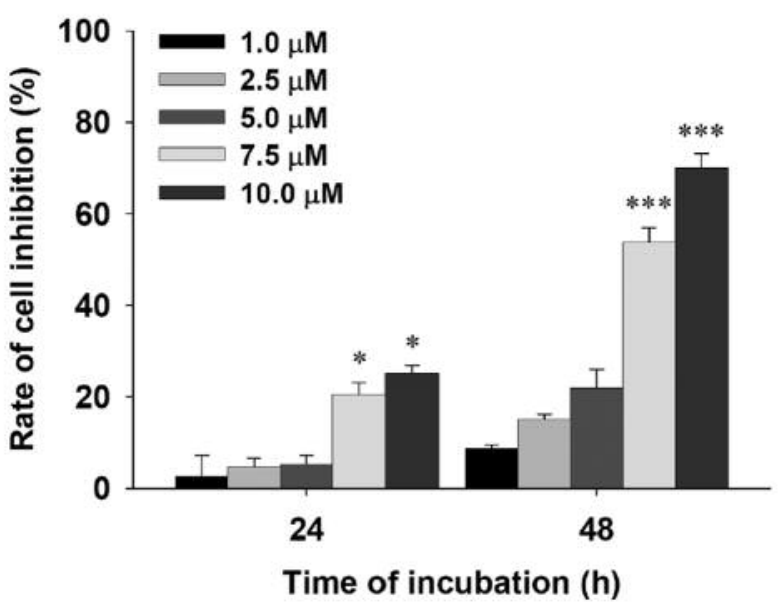

Figure 1. Cantharidin (CTD) affects the percentage of viable NCI-H460 cells. NCI-H460 cells $\left(5 \times 10^{4}\right.$ cells/well $)$ were incubated with $0,1,2.5,5.0$, 7.5 and $10.0 \mu \mathrm{M}$ of CTD for $24 \mathrm{~h}$ and $48 \mathrm{~h}$ before cells were harvested and the percentage of viable cells $(A)$ were determined by flow cytometry; percentage of inhibition $(B)$ was calculated as described in Materials and Methods. ${ }^{*} p<0.05$, *** $p<0.001$ : significant difference between $C T D$ treated groups and the control as analyzed by the Student's t-test.

B demonstrate a significant dose-dependent reduction of living cells with CTD at 2.5 and $5.0 \mu \mathrm{M}$ concentrations; thus, these concentrations were selected for further migration and invasion experiments.

CTD inhibited the cell migration and invasion of NCI-H46O cells. To determine the degree of inhibition of CTD on NCIH460 cell migration and invasion, we performed a transwell cell migration and invasion assay. The cells were cultured in presence and absence of CTD, examined, counted and photographed (Figures 2 and 3). We found that CTD significantly inhibited cell migration by $20 \%$ and $50 \%$ for 2.5 and $5.0 \mu \mathrm{M}$ at $24 \mathrm{~h}$, while inhibited cell migration by 
(A) Time of incubation (h)
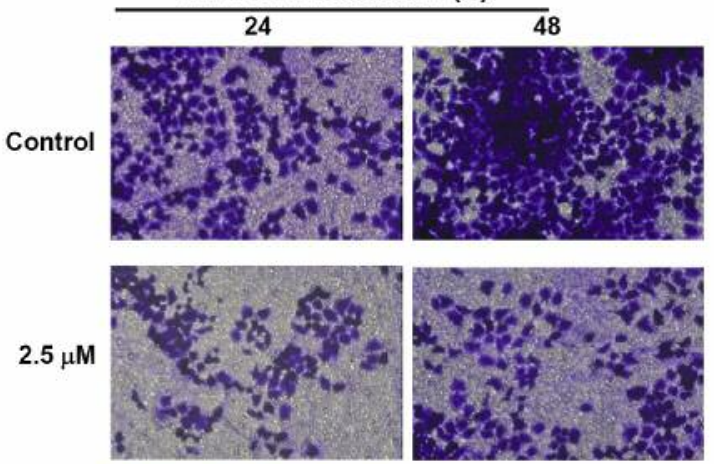

$5.0 \mu \mathrm{M}$
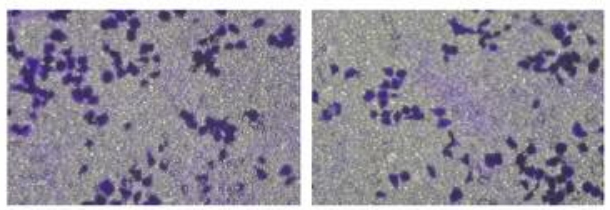

(B)

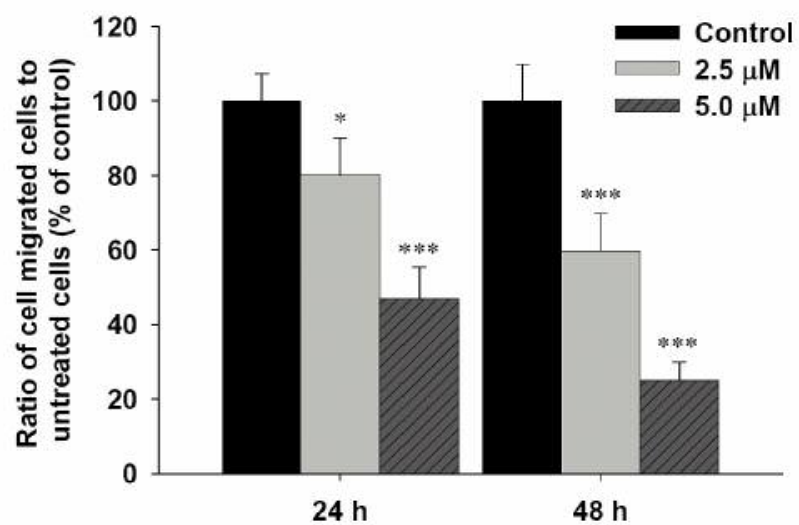

Figure 2. Cantharidin (CTD) suppresses the migration of NCI-H460 cells in vitro. Cells $\left(5 \times 10^{4}\right.$ cells/well $)$ were placed on a filter coated with collagen and, then, various concentrations of CTD were added to the well and incubated for 24 and $48 \mathrm{~h}$. Cells that penetrated to the lower surface of the filter were stained with crystal violet and photographed under a light microscope at $\times 200(A)$; cells were counted and percentage of inhibition was calculated $(B)$. Results were obtained from three independent experiments. ${ }^{*} p<0.05$, $* * * p<0.001$ : significant difference between $C T D$ treated groups and the control as analyzed by the Student's t-test.

$40 \%$ and $70 \%$ for 2.5 and $5.0 \mu \mathrm{M}$ at $48 \mathrm{~h}$ compared to control cells (Figure 2A and B). Results (Figure 3A and B) also indicated that treating NCI-H460 cells with CTD significantly $(p<0.05)$ reduced the invasion ability by 20 $50 \%$ in the $24-\mathrm{h}$ treatment and reduced cell invasion by $70 \%$ in the 48 -h treatment at concentrations of 2.5 and $5.0 \mu \mathrm{M}$, respectively, compared to control cells. Both inhibition of migration and invasion in NCI-H460 cells are concentrationdependent, suggesting CTD to be an inhibitor of lung cancer cell migration and invasion.
(A)

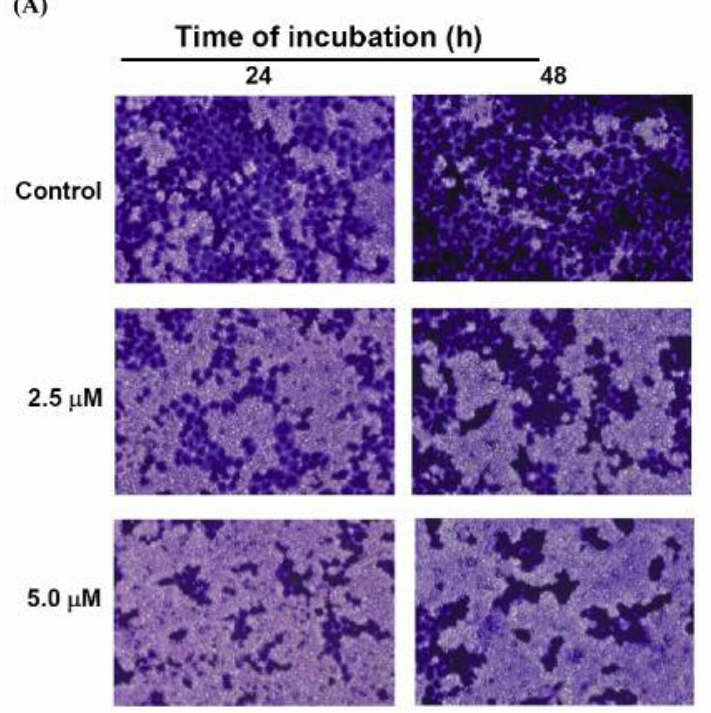

(B)

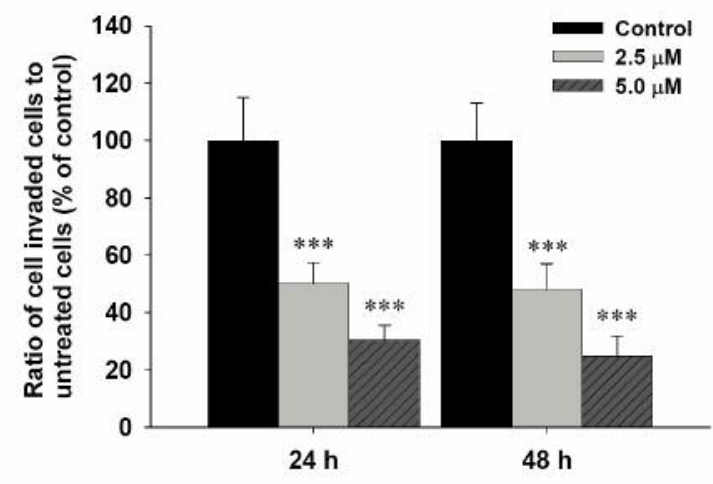

Figure 3. Cantharidin (CTD) suppresses the invasion of NCI-H460 cells in vitro. Cells $\left(5 \times 10^{4}\right.$ cells/well $)$ that penetrated Matrigel to the lower surface of the filter were stained with crystal violet and photographed under a light microscope at $\times 200$ (A); cells were counted and percentage of inhibition was calculated $(B)$. Results were obtained from three independent experiments. ${ }^{*} p<0.05$ shows a significant difference between $C T D$-treated groups and the control as analyzed by Student's $t$-test.

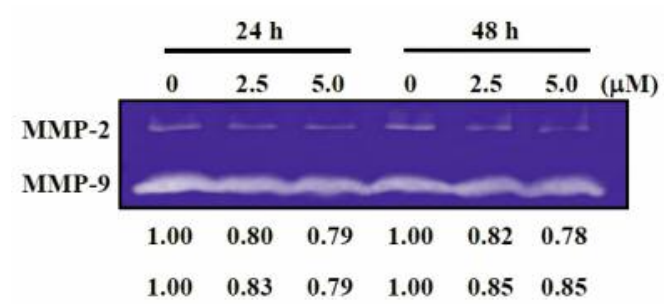

Figure 4. Cantharidin (CTD) affects the activities of MMP-2/-9 in NCIH460 cells. Cells $\left(5 \times 10^{4}\right.$ cells/well $)$ were incubated with 0, 2.5, 5.0 $\mu \mathrm{M}$ of CTD for 24 and $48 \mathrm{~h}$ and their conditioned medium was used for gelatin zymography as described in Materials and Methods. The different activity of MMP-2/-9 was determined by densitometric analysis. The results are expressed as a percentage of the control (100\%). 

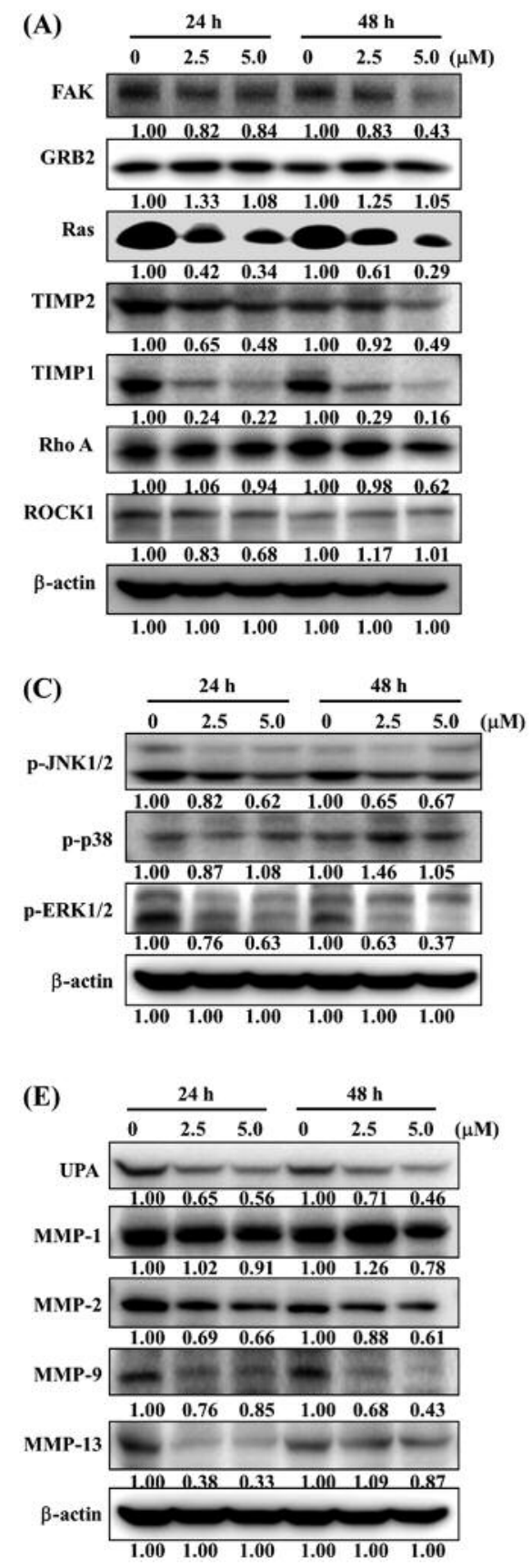

CTD inhibited the activity of MMP-2/-9 of NCI-H460 cells. To confirm the role of MMP-2/-9 activity in NCI-H460 cells, we performed gelatin zymography to detect the gelatinolytic activity in conditioned media of NCI-H460 cells treated with CTD. The cells were incubated with CTD $(2.5$ and $5.0 \mu \mathrm{M})$ for 24 and $48 \mathrm{~h}$ and the gelatinolytic activity of MMP-2/-9 was studied. As shown in Figure 4, MMP-2/-9 were shown to be decreased in a dose- and time-dependent manner.
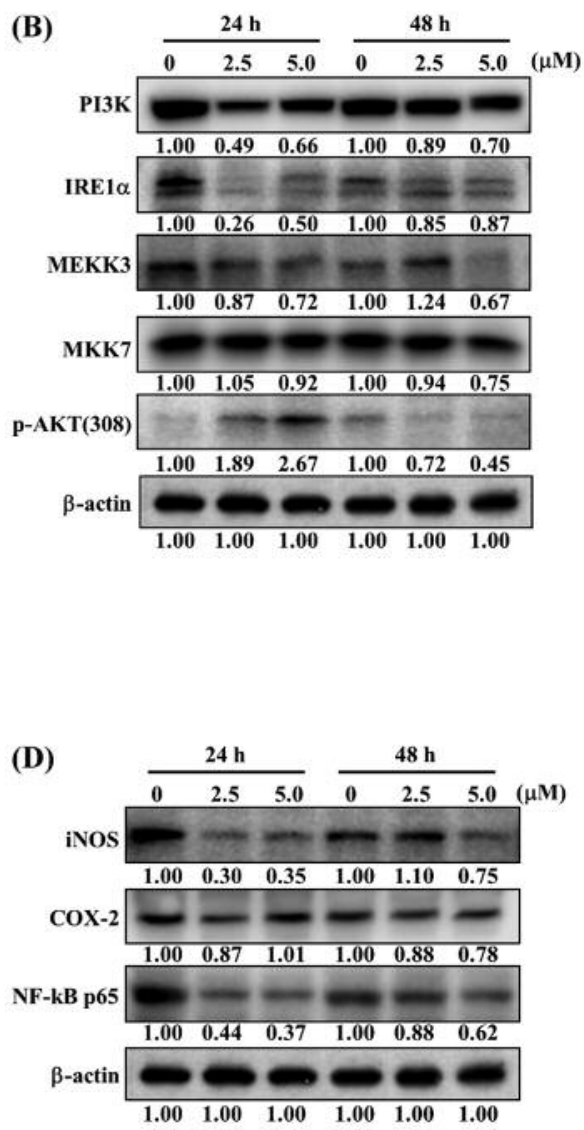

Figure 5. Cantharidin (CTD) affects the levels of associated proteins in migration and invasion of NCI-H460 cells. Cells $\left(5 \times 10^{5}\right.$ cells/well $)$ were treated with CTD 0, $2.55 .0 \mu M$ for 24 and $48 \mathrm{~h}$ and, then, the concentration of total proteins was determined by SDS-PAGE gel electrophoresis, as described in the Materials and Methods section. The levels of FAK, GRB2, Ras, TIMP2, TIMP1, Rho A, ROCK-1 (A), PI3K, IRE-1 $\alpha, M E K K 3, M K K 7, p-A K T(308)(B), p-J N K 1 / 2, p-E R K 1 / 2, p-p 38$ (C), iNOS, COX-2, NF-kB p65 (D), UPA, MMP-1, -2,- 9, -13 (E) were estimated by western blotting, as described in Materials and Methods.

CTD alters levels of proteins associated with migration and invasion of NCI-H460 cells. MMP-2/-9 are potential targets for anti-metastatic drug function. To further explore the link between FAK and MMPs in NCI-H460 cells after exposure to CTD, as FAK has been shown to be associated with MMP-9 production in cholangiocarcinoma (34), we investigated the effects of CTD on MMP-2/-9 and associated upstream protein levels in NCI-H460 cells. CTD significantly reduced protein 


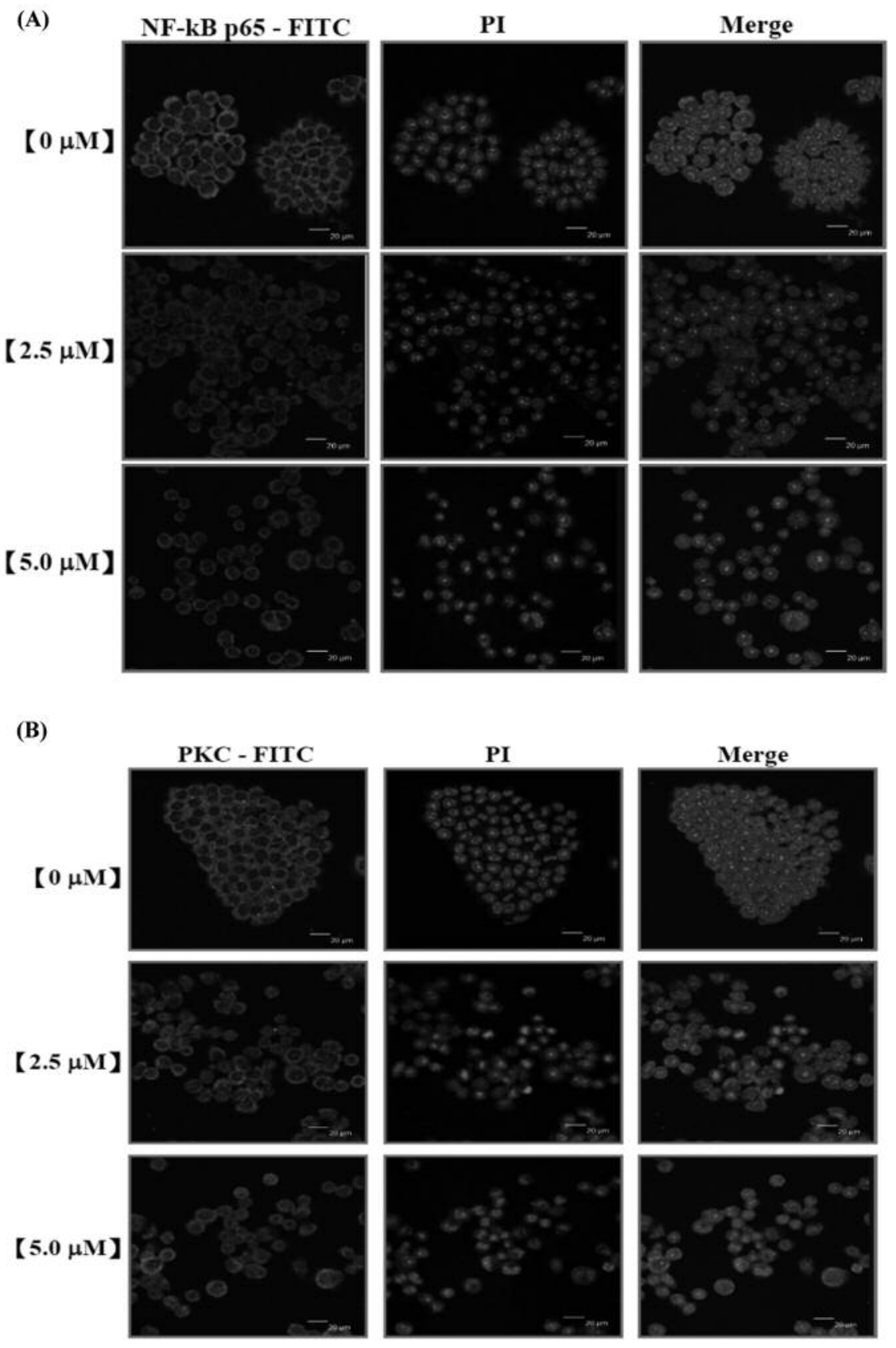

Figure 6. Cantharidin (CTD) affects the NF-kB p65 and PKC expression in NCI-H460 cells. Cells $\left(5 \times 10^{4}\right.$ cells/well $)$ were placed on 6-well chamber slides and treated with CTD $(2.5,5.0 \mu \mathrm{M})$ for $24 \mathrm{~h}$, fixed and stained using anti-NF-kB p65 and PKC antibodies (1:100) overnight and, subsequently, stained with a secondary antibody (FITC-conjugated goat anti-mouse IgG at 1:100 dilution) (green fluorescence) followed by PI (red fluorescence) for nuclear staining. Photomicrographs were obtained using a Leica TCS SP2 confocal spectral microscope as described in Materials and Methods.

levels of FAK, GRB2, Ras, TIMP2, TIMP1, Rho A, ROCK1 (Figure 5A), PI3K, IRE1 $\alpha$, MEKK3, MKK7, p-AKT(308) (Figure 5B), p-JNK1/2, p-p38, p-ERK1/2 (Figure 5C), iNOS, COX-2, NF-kB p65 (Figure 5D), UPA and MMP-1, -2, -9, 13 (Figure 5E). The protein levels were decreased in CTDtreated cells compared to untreated cells.
CTD alters translocation of NF- $\mathrm{kB}$ p 65 and PKC in NCI-H460 cells. To further investigate a possible mechanism of NF-kB p65 and PKC signaling pathway of MMP-2/-9 affected by CTD, we examined the NF-kB p65 and PKC nuclear translocation using the confocal microscopy immunofluorescent imaging technique. We observed that CTD-treated NCI-H460 cells exhibited 


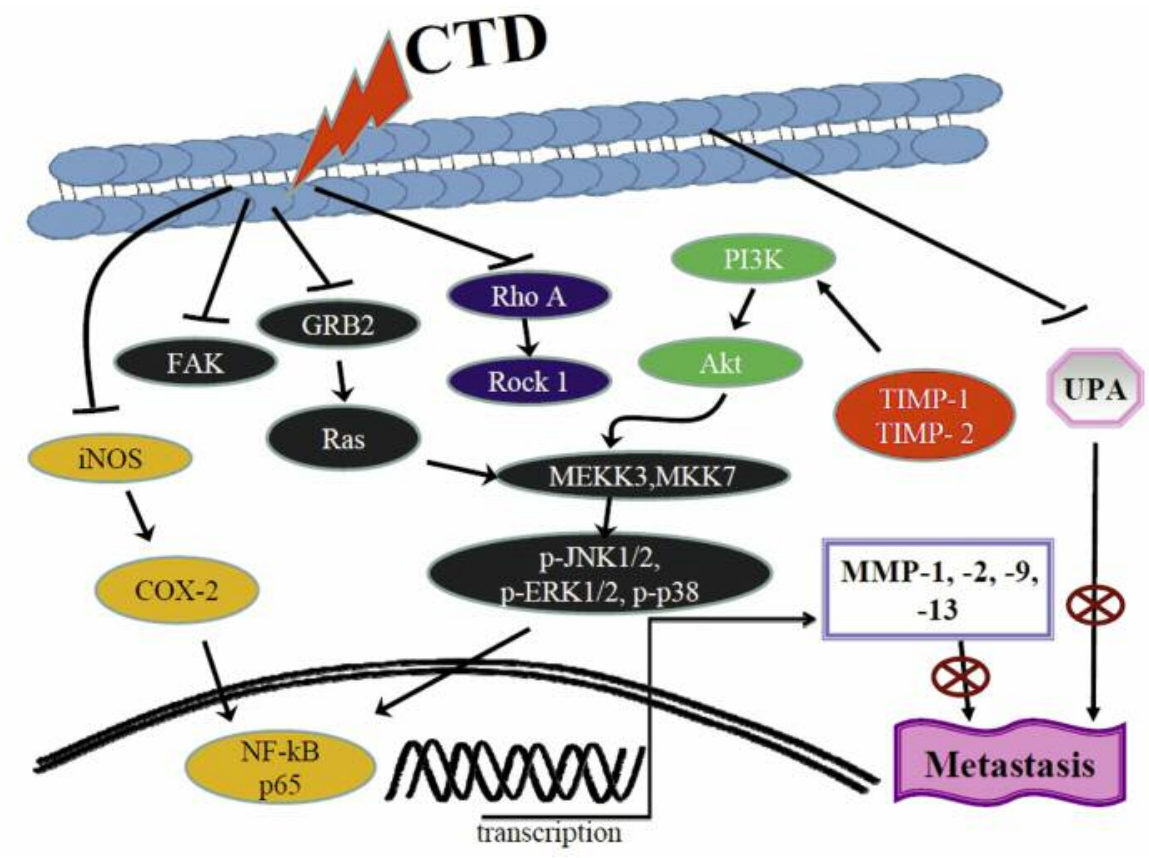

Figure 7. The possible signaling pathways for cantharidin (CTD)-inhibited migration and invasion of NCI-H460 human lung cancer cells.

significantly decreased presence of NF-kB p65 in nuclei (Figure 6A) but not decreased expression of PKC (Figure 6B). The functional consequence and the underlying mechanism of the nuclear NF-kB p65 and PKC translocation in cancer cells needs to be further explored.

\section{Discussion}

It is well known that cancer cells are of high invasion and migration ability leading to metastasis that proceeds through a complex multistep process involving cell adhesion, proteolysis degradation of extracellular matrix (ECM), angiogenesis and invasion (34). Thus, several studies and development of new anticancer drugs are revolving around anti-metastasis research (35). Although numerous evidences have shown that CTD induces cytotoxic cell death through cell-cycle arrest and induction of apoptosis in many human cancer cell lines, there is still no report showing inhibition of migration and invasion in human lung cancer NCI-H460 cells by CTD. Herein, we investigated the effects of CTD on adhesion, migration and invasion of human lung cancer NCIH460 cells in vitro.

A transwell assay was used for examining cell migration and invasion of NCI-H460 cells and whether or not these processes could be affected by CTD. We found that CTD inhibited cell migration (Figure $2 \mathrm{~A}$ and $\mathrm{B}$ ) and invasion (Figure 3A and B) in a concentration- and time-dependent manner. Our results indicated that CTD-suppressed cell migration and invasion may be through the inhibition of cell attachment (adhesion) on the basement membrane based on the reduction of cell adhesion (data not shown).

It is well documented that proteinase-related cell matrix degradation plays an important role in cancer cell metastasis; furthermore, increased levels of MMPs and UPA are associated with increased cancer cell angiogenesis, migration and invasion (36). Since it has already been reported that MMP-2/-9 play an important role in cancer cell migration and invasion, we investigated whether or not CTD could affect the activities of MMP-2/-9 in NCI-H460 cells. By using gelatin zymography, it was shown that CTD inhibited the activities of MMP-2/-9 in NCI-H460 cells (Figure 4). In addition, the expression levels of MMP-2/-9 proteins were also dramatically inhibited by CTD using western blotting (Figure 5E).

It is well known that MMP-2/-9 and UPA play important roles in cancer invasion and metastasis $(13,14)$. Studies have shown that the transcription of $M M P-2 /-9$ genes is regulated by upstream regulatory factors, including $N F-\mathrm{KB}$ p65, c-Jun and AP-1 (37-39). We, thus, examined the expression of NF-kB p65 in CTD-treated NCI-H460 cells by western blot analysis and showed a notable reduction of NF-kB p65 levels (Figure 5D) when compared to the control groups. Confocal laser microscopy examination reconfirmed that CTD suppressed NF-kB p65 translocation to nuclei (Figure 6A) and that, also, CTD decreased the protein expression of UPA (Figure 5E). The PI3K-AKT signaling 
pathways have been shown to play an important role in MMPs for UPA gene regulation, cell survival and invasion $(40,41)$. Here, we demonstrated that CTD inhibited the protein expression of PI3K, AKT and UPA (Figure 5B and $5 \mathrm{E})$. Since cancer cell adhesion, invasion, metastasis and angiogenesis are associated with the activation of $\mathrm{NF}-\mathrm{kB}$ p65 and AP-1 downstream of MAPK or PI3K-AKT pathways $(42,43)$, we further investigated CTD action on MAPK signaling pathway. The results showed that CTD suppressed the protein expression of p38, JNK and ERK in NCI-H460 cells. Based on these observations, it can be speculated that CTD inhibits the migration and invasion of NCI-H460 cells through the inhibition of MAPK signaling pathways; however, further investigations are needed.

In the present study, it was shown that CTD inhibits NCIH460 cells' adhesion, invasion and migration by regulating the activities of metastasis-associated proteases and their natural inhibitors. CTD inhibited the MAPK (p38, ERK and JNK) signaling pathway by reducing AKT, as well as NF-kB p65, leading to MMP-2/-9 down-regulation and UPA protein expression (Figure 7). Our results provide substantial evidence that CTD may be a potential candidate for developing preventive agents against human lung cancer metastasis. CTD should be tested further in vivo to justify its effectiveness in the prevention of lung cancer invasion or migration in animal models.

\section{Conflicts of Interest}

The Authors declare that there are no conflicts of interest.

\section{Acknowledgements}

This work was supported by the grants CMU103-ASIA-01 from China Medical University, Taichung, Taiwan. Experiments and data analysis were performed in part through the use of the Medical Research Core Facilities Center, Office of Research \& Development at China medical University, Taichung, Taiwan.

\section{References}

1 Sporn MB and Suh N: Chemoprevention of cancer. Carcinogenesis 21: 525-530, 2000.

2 Zhou J, Chen Y, Lang JY, Lu JJ and Ding J: Salvicine inactivates beta 1 integrin and inhibits adhesion of MDA-MB-435 cells to fibronectin via reactive oxygen species signaling. Mol Cancer Res 6: 194-204, 2008.

3 Hazan RB, Qiao R, Keren R, Badano I and Suyama K: Cadherin switch in tumor progression. Ann NY Acad Sci 1014: 155-163, 2004.

4 Makrilia N, Kollias A, Manolopoulos L and Syrigos K: Cell adhesion molecules: role and clinical significance in cancer. Cancer Invest 27: 1023-1037, 2009.

5 Khan $\mathrm{N}$ and Mukhtar H: Cancer and metastasis: prevention and treatment by green tea. Cancer Metastasis Rev 29: 435-445, 2010 .
6 Rieger-Christ KM, Lee P, Zagha R, Kosakowski M, Moinzadeh A, Stoffel J, Ben-Ze'ev A, Libertino JA and Summerhayes IC: Novel expression of $\mathrm{N}$-cadherin elicits in vitro bladder cell invasion via the Akt signaling pathway. Oncogene 23: 47454753, 2004.

7 Babykutty S, Suboj P, Srinivas P, Nair AS, Chandramohan K and Gopala S: Insidious role of nitric oxide in migration/invasion of colon cancer cells by upregulating MMP-2/9 via activation of cGMP-PKG-ERK signaling pathways. Clin Exp Metastasis 29: 471-492, 2012.

8 Dung TD, Feng CC, Kuo WW, Pai P, Chung LC, Chang SH, Hsu HH, Tsai FJ, Lin YM and Huang CY: Suppression of plasminogen activators and the MMP-2/-9 pathway by a Zanthoxylum avicennae extract to inhibit the HA22T human hepatocellular carcinoma cell migration and invasion effects in vitro and in vivo via phosphatase $2 \mathrm{~A}$ activation. Biosci Biotechnol Biochem 77: 1814-1821, 2013.

9 Liotta LA, Tryggvason K, Garbisa S, Hart I, Foltz CM and Shafie S: Metastatic potential correlates with enzymatic degradation of basement membrane collagen. Nature 284: 6768, 1980.

10 Coussens LM, Fingleton B and Matrisian LM: Matrix metalloproteinase inhibitors and cancer: Trials and tribulations. Science 295: 2387-2392, 2002.

11 Egeblad $M$ and Werb $\mathrm{Z}$ : New functions for the matrix metalloproteinases in cancer progression. Nat Rev Cancer 2: 161-174, 2002.

12 Shan B, Li W, Yang SY and Li ZR: Estrogen up-regulates MMP2/9 expression in endometrial epithelial cell via VEGFERK1/2 pathway. Asian Pac J Trop Med 6: 826-830, 2013.

13 Birkedal-Hansen H, Moore WG, Bodden MK, Windsor LJ, Birkedal-Hansen B, DeCarlo A and Engler JA: Matrix metalloproteinases: a review. Crit Rev Oral Biol Med 4: 197250, 1993.

14 Dutta S, Bandyopadhyay C, Bottero V, Veettil MV, Wilson L, Pins MR, Johnson KE, Warshall C and Chandran B: Angiogenin interacts with the plasminogen activation system at the cell surface of breast cancer cells to regulate plasmin formation and cell migration. Mol Oncol 8: 483-507, 2014.

15 Andreasen PA, Egelund R and Petersen HH: The plasminogen activation system in tumor growth, invasion, and metastasis. Cell Mol Life Sci 57: 25-40, 2000.

16 Wang GS: Medical uses of mylabris in ancient China and recent studies. J Ethnopharmacol 26: 147-162, 1989.

17 Honkanen RE: Cantharidin, another natural toxin that inhibits the activity of serine/threonine protein phosphatases types 1 and 2A. FEBS Lett 330: 283-286, 1993.

18 Efferth T, Rauh R, Kahl S, Tomicic M, Bochzelt H, Tome ME, Briehl MM, Bauer R and Kaina B: Molecular modes of action of cantharidin in tumor cells. Biochem Pharmacol 69: 811-818, 2005.

19 Li W, Xie L, Chen Z, Zhu Y, Sun Y, Miao Y, Xu Z and Han X: Cantharidin, a potent and selective PP2A inhibitor, induces an oxidative stress-independent growth inhibition of pancreatic cancer cells through G2/M cell-cycle arrest and apoptosis. Cancer Sci 101: 1226-1233, 2010.

20 Huang WW, Ko SW, Tsai HY, Chung JG, Chiang JH, Chen KT, Chen YC, Chen HY, Chen YF and Yang JS: Cantharidin induces $\mathrm{G} 2 / \mathrm{M}$ phase arrest and apoptosis in human colorectal cancer colo 205 cells through inhibition of CDK1 activity and caspasedependent signaling pathways. Int J Oncol 38: 1067-1073, 2011. 
21 Huan SK, Lee HH, Liu DZ, Wu CC and Wang CC: Cantharidininduced cytotoxicity and cyclooxygenase 2 expression in human bladder carcinoma cell line. Toxicology 223: 136-143, 2006.

22 Kuo JH, Chu YL, Yang JS, Lin JP, Lai KC, Kuo HM, Hsia TC and Chung JG: Cantharidin induces apoptosis in human bladder cancer TSGH 8301 cells through mitochondria-dependent signal pathways. Int J Oncol 37: 1243-1250, 2010.

23 Williams LA, Moller W, Merisor E, Kraus W and Rosner H: In vitro anti-proliferation/cytotoxic activity of cantharidin (Spanish Fly) and related derivatives. West Indian Med J 52: 10-13, 2003

24 Wang CC, Wu CH, Hsieh KJ, Yen KY and Yang LL: Cytotoxic effects of cantharidin on the growth of normal and carcinoma cells. Toxicology 147: 77-87, 2000.

25 Sagawa M, Nakazato T, Uchida H, Ikeda Y and Kizaki M: Cantharidin induces apoptosis of human multiple myeloma cells via inhibition of the JAK/STAT pathway. Cancer Sci 99: 18201826, 2008.

26 Epstein WL and Kligman AM: Treatment of warts with cantharidin. AMA Arch Derm 77: 508-511, 1958.

27 Chang YM, Velmurugan BK, Kuo WW, Chen YS, Ho TJ, Tsai CT, Ye CX, Tsai CH, Tsai FJ and Huang CY: Inhibitory effect of alpinate Oxyphyllae fructus extracts on Ang II-induced cardiac pathological remodeling-related pathways in $\mathrm{H} 9 \mathrm{c} 2$ cardiomyoblast cells. Biomedicine 3: 148-152, 2013.

28 Ji BC, Yu CC, Yang ST, Hsia TC, Yang JS, Lai KC, Ko YC, Lin JJ, Lai TY and Chung JG: Induction of DNA damage by deguelin is mediated through reducing DNA repair genes in human non-small cell lung cancer NCI-H460 cells. Oncol Rep 27: 959-964, 2012.

29 Wu KC, Yang ST, Hsia TC, Yang JS, Chiou SM, Lu CC, Wu RS and Chung JG: Suppression of cell invasion and migration by propofol are involved in down-regulating matrix metalloproteinase-2 and p38 MAPK signaling in A549 human lung adenocarcinoma epithelial cells. Anticancer Res 32: 4833-4842, 2012.

30 Lin SS, Lai KC, Hsu SC, Yang JS, Kuo CL, Lin JP, Ma YS, Wu $\mathrm{CC}$ and Chung JG: Curcumin inhibits the migration and invasion of human A549 lung cancer cells through the inhibition of matrix metalloproteinase-2 and -9 and Vascular Endothelial Growth Factor (VEGF). Cancer Lett 285: 127-133, 2009.

31 Lin MC, Tsai SY, Wang FY, Liu FH, Syu JN and Tang FY: Leptin induces cell invasion and the up-regulation of matrilysin in human colon cancer cells. Biomedicine 3: 174-180, 2013.

32 Lai WW, Hsu SC, Chueh FS, Chen YY, Yang JS, Lin JP, Lien JC, Tsai $\mathrm{CH}$ and Chung JG: Quercetin inhibits migration and invasion of SAS human oral cancer cells through inhibition of NF-kappaB and matrix metalloproteinase-2/-9 signaling pathways. Anticancer Res 33: 1941-1950, 2013.

33 Liu KC, Huang AC, Wu PP, Lin HY, Chueh FS, Yang JS, Lu $\mathrm{CC}$, Chiang JH, Meng M and Chung JG: Gallic acid suppresses the migration and invasion of PC-3 human prostate cancer cells via inhibition of matrix metalloproteinase-2 and -9 signaling pathways. Oncol Rep 26: 177-184, 2011.
34 Weng CJ and Yen GC: The in vitro and in vivo experimental evidences disclose the chemopreventive effects of Ganoderma lucidum on cancer invasion and metastasis. Clin Exp Metastasis 27: 361-369, 2010.

$35 \mathrm{Wu} \mathrm{X,} \mathrm{Zhu} \mathrm{Y,} \mathrm{Yan} \mathrm{H,} \mathrm{Liu} \mathrm{B,} \mathrm{Li} \mathrm{Y,} \mathrm{Zhou} \mathrm{Q} \mathrm{and} \mathrm{Xu} \mathrm{K:}$ Isothiocyanates induce oxidative stress and suppress the metastasis potential of human non-small cell lung cancer cells. BMC Cancer 10: 269, 2010.

36 Shia CS, Suresh G, Hou YC, Lin YC, Chao PD and Juang SH: Suppression on metastasis by rhubarb through modulation on MMP-2 and uPA in human A549 lung adenocarcinoma: an ex vivo approach. J Ethnopharmacol 133: 426-433, 2011.

37 Vayalil PK and Katiyar SK: Treatment of epigallocatechin-3gallate inhibits matrix metalloproteinases- 2 and -9 via inhibition of activation of mitogen-activated protein kinases, c-jun and NFkappaB in human prostate carcinoma DU-145 cells. Prostate 59: 33-42, 2004.

38 Cheung LW, Leung PC and Wong AS: Gonadotropin-releasing hormone promotes ovarian cancer cell invasiveness through cJun NH2-terminal kinase-mediated activation of matrix metalloproteinase (MMP)-2 and MMP-9. Cancer Res 66: 1090210910, 2006.

39 Zhang G, Luo X, Sumithran E, Pua VS, Barnetson RS, Halliday GM and Khachigian LM: Squamous cell carcinoma growth in mice and in culture is regulated by c-Jun and its control of matrix metalloproteinase-2 and -9 expression. Oncogene 25: 7260-7266, 2006.

40 Yang SF, Chen MK, Hsieh YS, Yang JS, Zavras AI, Hsieh YH, Su SC, Kao TY, Chen PN and Chu SC: Antimetastatic effects of Terminalia catappa L. on oral cancer via a down-regulation of metastasis-associated proteases. Food Chem Toxicol 48: 10521058, 2010.

41 Kim D, Kim S, Koh H, Yoon SO, Chung AS, Cho KS and Chung $\mathrm{J}$ : Akt/PKB promotes cancer cell invasion via increased motility and metalloproteinase production. FASEB J 15: 1953-1962, 2001.

42 Takada Y, Singh S and Aggarwal BB: Identification of a p65 peptide that selectively inhibits NF-kappa B activation induced by various inflammatory stimuli and its role in down-regulation of NF-kappaB-mediated gene expression and up-regulation of apoptosis. J Biol Chem 279: 15096-15104, 2004.

43 Aggarwal BB: Nuclear factor-kappaB: the enemy within. Cancer Cell 6: 203-208, 2004.
Received June 28, 2016

Revised July 14, 2016

Accepted July 15, 2016 